\title{
THE EFFECT OF THE INFESTATION WITH THREE SITOPHILUS SPECIES ON THE WEIGHTS OF GRAINS STORED UNDER LABORATORY CONDITIONS FOR ONE YEAR
}

\author{
M.E. Sweelam, A.M. Abd El-Raheem, Safaa M. Abo Taka and M. M. Mousa \\ Faculty of Agriculture, Menoufia University, Egypt.
}

Received: Sep. 16, 2019

Accepted: Oct. 7,2019

\begin{abstract}
This article aimed to study the effect of the infestation of Sitophilus species on the average weights of wheat, maize, and rice grains stored under laboratory conditions for one year. The average weights of grains were gradually decreased along year months from $10 \mathrm{~kg}$ reaching $7 \mathrm{~kg}$ at the end of the experiment. The wheat weevil, Sitophilus granarius insects appeared in the wheat grains at the second month of storage with a few numbers (1 insect / $\mathrm{kg}$ grains) and gradually increased along year months recording 80 insect / $\mathrm{kg}$ grains at the end of the experiment. The average weights of maize grains were gradually decreased along year months from $10 \mathrm{~kg}$ reaching $6 \mathrm{~kg}$ at the end of the experiment. Results also indicated that there were no damage or infestation at the first month of storing, meanwhile the damage start to increase at the third month recording $5 \%$, and $7 \%$ after 4 months, and continued in increase recording $65 \%$ after 12 months of storing. The maize weevil, Sitophilus zeamais insects appeared in the maize grains at the second month of storing with a few numbers (2 insect / $\mathrm{kg}$ grains) and gradually increased along year months reaching 75 insect / $\mathrm{kg}$ grains at the end of the experiment. The average weights of rice grains were gradually decreased along year months from $10 \mathrm{~kg}$ reaching $6 \mathrm{~kg}$ at the end of the experiment. The rice weevil, Sitophilus oryzae insects appeared in the rice grains at the second month of storing with a few numbers (2 insects / kg grains) and gradually increased along year months recording 75 insects / $\mathrm{kg}$ grains at the end of the experiment.
\end{abstract}

Key words: Sitophilus spp, store insects, ecology, grain, grains

\section{INTRODUCTION}

Stored grains and legumes are subject to insect infestation and deterioration from molds and bacteria. The granary weevil, Sitophilus granarius (Linnaeus, 1758), Sitophilus zeamais (Motschulsky, 1855) and Sitophilus oryzae (L.) are the most widespread and destructive primary insect pests of stored cereals.

The wheat weevil (Sitophilus granarius), also known as the grain weevil or granary weevil, occurs all over the world and is a common pest in many places. It can cause significant damage to stored grains. The females lay many eggs and the larvae eat the inside of the grain kernels. Rice weevil, Sitophilus oryzae (L.) (Coleoptera: Curculionidae) is a major pest of stored grain throughout the world.

Sitophilus zeamais (Motschulsky), the maize weevil, is a serious pest of economic importance in stored products in tropical and subtropical countries; infestation often starts in the field, but serious damage is done during maize storage. Suleiman et al. (2015) evaluated weight loss by Sitophilus zeamais infestation, and weight of powder produced were assessed at the end of each storage time. As expected, severe damage was observed at $27^{\circ} \mathrm{C}$ and $90 \mathrm{~d}$ for all maize varieties.

From the previous points, this study was conducted to study the effect of the 
infestation of three Sitophilus species on the weights of three infested grains stored under laboratory conditions for one year.

\section{MATERIALS AND METHODS}

\section{Target Insects:}

The most known species of stored grain insects were investigated in this research are: the granary weevil, Sitophilus granarius (L.), the maize weevil, Sitophilus zeamais (Motschulsky), and the rice weevil, Sitophilus oryzae (L.).

Pure cultures of each weevil were reared under laboratory conditions of 25 \pm 5 ㄷ , and $56 \pm 5 \%$ Relative humidity where it was reared in glass boxes $60 \times 40$ $x 30 \mathrm{~cm}$ covered with muslin material on the three hosts, wheat, maize, and rice.

\section{Tested grains:}

Cereal grains which considered one of the most important crops in Egypt and all over the world were used in these experiments. These grains were Wheat (Triticum aestivum) variety Sakha 93 and Maize (Zea mays) Variety High Tech 2031, and Rice (Oryza sativa) Giza 179. Tested grains were dried very well by exposing it to the sun shine for three days and stored for one year in jute bags under laboratory conditions $25 \pm 5 \stackrel{\circ}{ } \mathrm{C}$, and $56 \pm$ $5 \%$ Relative humidity.

\section{Store procedure:}

These bags are naturally material and made of jute fibers where its pores allow both air and humidity to be merged with the atmosphere around the bag and its capacity $10 \mathrm{~kg}$.

Each crop was replicated five times as well as control bags.

\section{Sampling and inspection:}

All samples of stored grains were externally examined by transparency method as the grain samples were soaked into a solution consists of water, phenol, lactic acid, and glycerin (2:2:2:1) for 3 days, then was examined by eye and the aid of handle lens $(6 \mathrm{x})$ to determine the visible infested grains, and calculate the infestation degree. Average weight of grains $(\mathrm{kg})$, Damage \%, No of insects / kg, No of insects / kg were determined every 15 days for one year.

Statistical analysis:

Collected data were subjected to statistical analysis of variance (ANOVA) at $5 \%$ probability, and the measurements were separated using Duncan's Multiple Range Test (DMRT) through CoStat software program (Version 6.400). CoStat version 6.400 Copyright (C) 1998-2008 Cohort Software.798 Lighthouse Ave. PMB 320, Monterey, CA, 93940, USA.

\section{RESULTS AND DISCUSSION}

The obtained results in Table (1) show the effect of the infestation of Sitophilus granarius on the average weights of wheat grains stored under laboratory conditions for one year.

The average weights of grains were gradually decreased along year months from $10 \mathrm{~kg}$ reaching $7 \mathrm{~kg}$ at the end of the experiment.

Statistical analysis of the results indicated that there were significant differences among year months (LSD5 \% = 1.048).

Results also indicated that there were no damage or infestation at the first two months of storage, meanwhile the damage start to increase at the third month recording $1 \%$, and $2 \%$ after 4 months, and continued in increase recording $58 \%$ after 12 months of storage.

The wheat weevil, Sitophilus granarius insects appeared in the wheat grains at the second month of storage with a few numbers ( 1 insect / $\mathrm{kg}$ grains) and gradually increased along year months recording 80 insect / $\mathbf{k g}$ grains at the end of the experiment. 
Table (1): The effect of infestation of Sitophilus granarius on the weights of wheat grains stored under laboratory conditions for one year

\begin{tabular}{|c|c|c|c|}
\hline Sampling dates & $\begin{array}{c}\text { Average weight } \\
\text { of grains }(\mathbf{k g})\end{array}$ & Damage $\%$ & No of insects / kg \\
\hline $15-06-2014$ & $10 a$ & 0 & 1 \\
\hline $30-06-2014$ & $10 a$ & 0 & 2 \\
\hline $15-07-2014$ & $10 a$ & 0 & 2 \\
\hline $30-07-2014$ & $10 a$ & 0 & 2 \\
\hline $15-08-2014$ & $10 a$ & 1 & 2 \\
\hline $30-08-2014$ & $10 a$ & 1 & 2 \\
\hline $15-09-2014$ & $10 a$ & 2 & 2 \\
\hline $30-09-2014$ & $9.7 a b$ & 2 & 3 \\
\hline $15-10-2014$ & $9.5 \mathrm{abc}$ & 4 & 4 \\
\hline $30-10-2014$ & $9.5 \mathrm{abc}$ & 6 & 5 \\
\hline $15-11-2014$ & 9bcd & 6 & 5 \\
\hline $30-11-2014$ & 9bcd & 8 & 7 \\
\hline $15-12-2014$ & $8.7 \mathrm{cde}$ & 10 & 8 \\
\hline $30-12-2014$ & $8.5 \mathrm{def}$ & 10 & 9 \\
\hline $15-01-2015$ & $8.5 \mathrm{def}$ & 11 & 9 \\
\hline $30-01-2015$ & 8.3defg & 11 & 10 \\
\hline $15-02-2015$ & 8efgh & 12 & 15 \\
\hline 28-02-2015 & 8efgh & 12 & 20 \\
\hline $15-03-2015$ & 8 efgh & 15 & 30 \\
\hline 30-03-2015 & $7.7 \mathrm{fghi}$ & 17 & 35 \\
\hline $15-04-2015$ & $7.5 \mathrm{ghi}$ & 22 & 50 \\
\hline $30-04-2015$ & $7.5 \mathrm{ghi}$ & 35 & 60 \\
\hline $15-05-2015$ & $7.3 \mathrm{hi}$ & 54 & 75 \\
\hline $30-05-2015$ & $7 i$ & 58 & 80 \\
\hline LSD 5\% & 1.048 & - & - \\
\hline
\end{tabular}

Means in the column followed by different letter(s) are significantly different at $5 \%$ level

The obtained results in Table (2) show the effect of the infestation of Sitophilus zeamais on the average weights of maize grains stored under laboratory conditions for one year.

The average weights of grains were gradually decreased along year months from $10 \mathrm{~kg}$ reaching $6 \mathrm{~kg}$ at the end of the experiment.

Statistical analysis of the results indicated that there were significant differences among year months (LSD $5 \%$ $=0.580$ ). 
M.E. Sweelam, et al.,

Table (2): Weight of grains and damage in maize grains infested with Sitophilus zeamais

\begin{tabular}{|c|c|c|c|}
\hline Sampling dates & $\begin{array}{l}\text { Weight of grains } \\
(\mathbf{k g})\end{array}$ & $\begin{array}{c}\text { Damage } \\
\%\end{array}$ & Insects / kg \\
\hline 01-10-2014 & $10 a$ & 0 & 1 \\
\hline $15-10-2014$ & $10 a$ & 0 & 1 \\
\hline $30-10-2014$ & $10 a$ & 1 & 1 \\
\hline 15-11-2014 & $10 a$ & 3 & 1 \\
\hline $30-11-2014$ & $10 \mathrm{a}$ & 4 & 2 \\
\hline $15-12-2014$ & $10 a$ & 5 & 2 \\
\hline $30-12-2014$ & $9.7 \mathrm{ab}$ & 7 & 3 \\
\hline 15-01-2015 & $9.5 \mathrm{abc}$ & 7 & 4 \\
\hline $30-01-2015$ & $9.5 \mathrm{abc}$ & 7 & 5 \\
\hline $15-02-2015$ & $9.2 \mathrm{bcd}$ & 8 & 5 \\
\hline 28-02-2015 & $9.2 \mathrm{bcd}$ & 8 & 7 \\
\hline 15-03-2015 & 9cde & 10 & 7 \\
\hline $30-03-2015$ & 9cde & 12 & 8 \\
\hline $15-04-2015$ & $8.8 \mathrm{de}$ & 15 & 8 \\
\hline $30-04-2015$ & $8.8 \mathrm{de}$ & 19 & 9 \\
\hline $15-05-2015$ & $8.7 \mathrm{de}$ & 22 & 9 \\
\hline $30-05-2015$ & 8.5ef & 23 & 10 \\
\hline $15-06-2015$ & $8 \mathrm{fg}$ & 23 & 10 \\
\hline $30-06-2015$ & $7.5 \mathrm{gh}$ & 40 & 15 \\
\hline $15-07-2015$ & $7.5 \mathrm{gh}$ & 44 & 20 \\
\hline $30-07-2015$ & $7 \mathrm{hi}$ & 48 & 30 \\
\hline 15-08-2015 & $6.5 \mathrm{ij}$ & 52 & 50 \\
\hline $30-08-2015$ & $6.3 \mathrm{j}$ & 58 & 60 \\
\hline 15-09-2015 & $6 \mathrm{j}$ & 65 & 75 \\
\hline LSD $5 \%$ & 0.580 & - & - \\
\hline
\end{tabular}

Means in the column followed by different letter (s) are significantly different at $5 \%$ level

Results also indicated that there were no damage or infestation at the first month of storing, meanwhile the damage start to increase at the third month recording $5 \%$, and $7 \%$ after 4 months, and continued in increase recording 65 $\%$ after 12 months of storing .

The maize weevil, Sitophilus zeamais insects appeared in the maize grains at the third month of storing with a few numbers (2 insect / $\mathrm{kg}$ grains) and gradually increased along year months reaching 75 insect / $\mathrm{kg}$ grains at the end of the experiment.

The obtained results in Table (3) show the effect of the infestation with Sitophilus oryzae on the average weights 
of rice grains stored under laboratory conditions for one year.

The average weights of grains were gradually decreased along year months from $10 \mathrm{~kg}$ reaching $4 \mathrm{~kg}$ at the end of the experiment.

Statistical analysis of the results indicated that there were significant differences in the average weights of grains among year months (LSD $5 \%=$ 0.356).

The obtained results, also indicated that there were no damage or infestation at the first month of storing, meanwhile the damage start to increase at the third month recording $5 \%$, and $9 \%$ after 4 months, and continued in increase recording $72 \%$ after 12 months of storing .

Table (3): Weight of grains and damage in rice grains infested with Sitophilus oryzae

\begin{tabular}{|c|c|c|c|}
\hline Sampling dates & $\begin{array}{c}\text { Weight of grains } \\
\mathrm{kg}\end{array}$ & $\begin{array}{c}\text { Damage } \\
\%\end{array}$ & $\begin{array}{c}\text { Insects per } \\
\text { kg }\end{array}$ \\
\hline $01-10-2014$ & $10 a$ & 0 & 1 \\
\hline $15-10-2014$ & $10 a$ & 0 & 1 \\
\hline $30-10-2014$ & $10 a$ & 2 & 1 \\
\hline $15-11-2014$ & $10 a$ & 5 & 1 \\
\hline $30-11-2014$ & $10 a$ & 7 & 3 \\
\hline $15-12-2014$ & $10 a$ & 7 & 3 \\
\hline $30-12-2014$ & $9.2 b$ & 8 & 4 \\
\hline $15-01-2015$ & $9.2 \mathrm{~b}$ & 9 & 5 \\
\hline $30-01-2015$ & $9.0 \mathrm{bc}$ & 9 & 7 \\
\hline $15-02-2015$ & $9.0 \mathrm{bc}$ & 10 & 8 \\
\hline 28-02-2015 & $9.0 \mathrm{bc}$ & 12 & 9 \\
\hline $15-03-2015$ & $8.9 b c$ & 14 & 9 \\
\hline 30-03-2015 & $8.8 \mathrm{~cd}$ & 15 & 10 \\
\hline $15-04-2015$ & $8.8 \mathrm{~cd}$ & 18 & 12 \\
\hline $30-04-2015$ & $8.5 \mathrm{~d}$ & 21 & 14 \\
\hline $15-05-2015$ & $8.0 \mathrm{e}$ & 22 & 14 \\
\hline $30-05-2015$ & $7.0 \mathrm{f}$ & 30 & 18 \\
\hline $15-06-2016$ & $7.0 \mathrm{f}$ & 40 & 22 \\
\hline $30-06-2015$ & $6.5 \mathrm{~g}$ & 45 & 30 \\
\hline $15-07-2015$ & $6.0 \mathrm{~h}$ & 52 & 35 \\
\hline $30-07-2015$ & $5.5 i$ & 55 & 45 \\
\hline 15-08-2015 & $5.0 \mathrm{j}$ & 60 & 55 \\
\hline $30-08-2015$ & $4.5 \mathrm{k}$ & 65 & 70 \\
\hline $15-09-2015$ & 41 & 72 & 85 \\
\hline LSD $5 \%$ & 0.356 & & \\
\hline
\end{tabular}

Means in the column followed by different letter (s) are significantly different at $5 \%$ level 
The rice weevil, Sitophilus oryzae insects appeared in the rice grains at the third month of storing with a few numbers (3 insect / $\mathrm{kg}$ grains) and gradually increased along year months recording 85 insect / $\mathrm{kg}$ grains at the end of the experiment.

The rice weevil, Sitophilus oryzae insects appeared in the rice grains at the second month of storing with a few numbers (2 insects / $\mathrm{kg}$ grains) and gradually increased along year months recording 75 insects / $\mathrm{kg}$ grains at the end of the experiment.

The obtained results are in harmony with those of Abba et al. (1999) who found that storage of primed seeds under high $\mathrm{RH}$ condition beyond 15 days is deteriorative for germination and growth of rice. The primed rice seeds are recommended to store at vacuum or low $\mathrm{RH}$ or low temperature condition to ensure good crop establishment.

Kurdikeri et al. (1994) studied the extent of grain damage, loss in weight clue to infestation of 5 pairs of Rhizopertha dominica (F.) on the maize hybrids and revealed that percentage grain damage and loss in weight increased markedly with the increasing in storage period in all the hybrids.

Ramzon et al. (1994) studied the performance of different wheat varieties during storage in respect of losses caused by storage pests for two years.

Kurdikeri et al. (1995) estimated the weight loss in five maize hybrids, that were exposed to Sitophilus oryzae (L.) and Rhizopertha dominica (F.) and found that the hybrid Ganga safed 2 was most tolerant to these pests while all other hybrids were highly susceptible.

Lohar et al. (1995) revealed that percentage weight loss by Sitophilus granarius (L.) varied with both time intervals of infestation and the type of kernels provided as food and ovipositor substrate. After 90 days the percentage weight loss was significantly higher in maize kernels, followed by rice and wheat. Among the rice varieties, Basmati370 was significantly more susceptible to the attacks of S. granarius than IR-8 and IR-6. Among the wheat varieties, Anmol showed more quantative loss than mehran-89 and TJ-83. Positive and significantly correlation were recorded between percentage infested grain and weight loss.

Vowotor et al. (1995) investigated the effect of maize variety and storage on development of the maize weevil, Sitophilus zeamais (Motschulsky), under artificial infestation at $25 \pm 2{ }^{\circ} \mathrm{C}$ and $70 \pm 5 \%$ R.H. in the laboratory. The mean weight of the developing insect were not significantly influenced by storage form except for the first and third instar larvae which gave higher mean weights on shelled than unshelled grain. Both maize variety and storage form influenced the site of weevil emergence from the kernel.

Thukur and Sharma (1996) mentioned that the average weight loss in stored rice (unhusked) was $2.11 \%$ after natural infestation with Sitotroga cerealella (Oliv.), Rhizopertha dominica (F.), Sitophilus oryzae (L.), Tribolium confusum (Jacquelin du val) and Oryzaephilussurinamensis (L.).

Richter et al. (1997) evaluated the damage and losses of stored maize caused by Sitophilus zeamais (Motsch), Prostephanus truncalus (Horn) and Teretriosoma nigrescens after 8 months of storage. They indicated that the storage of loose grain in sacks gave the best results with the smallest damage and losses. The highest damage and losses occurred in cribs, whereas intermediate results were obtained in granarius. 
Danho et al. (2002) observe the effect of grain quantity on the oviposition, distribution of eggs, adult emergence, adult body weight and sex ratio of Sitophilus zeamais, an important pest of maize. Grains were infested $(90 \%)$ when less grain was present. Emergence of adult weevils was, however, the mean weight of the emerged adults was not significantly influenced by grain quantity.

Baoua et al. (2014) reported that storage pests are major constraints in the maize value chain, with losses reaching $30 \%$. Simple, low-cost triple bagging technology (now known as PICS e Purdue Improved Crop Storage) originally developed for postharvest storage of cowpea was evaluated for applicability to maize storage maize that had relatively high levels of infestation with Prostephanus truncatus Horn, Sitophilus zeamais Motschulsky, 1855 and/or Rhyzopertha dominica (F.). The percentage of damaged grains and the 100 grains weights in PICS bags were unchanged from what was recorded at the time the experiment was set up. Grain viability was well maintained; germination rates of grains from the PICS bags did not differ from that observed at the beginning of the experiment.

Suleiman et al. (2015) evaluated $S$. zeamais infestation on seven varieties of maize. Seven commercial maize varieties (white dent, yellow dent, orange flint, Indian flint, white popcorn, yellow popcorn and sweet corn), two temperature conditions $\left(10\right.$ and $\left.27^{\circ} \mathrm{C}\right)$ and three storage times $(30,60$, and $90 \mathrm{~d})$ were used. The moisture contents of all maize samples were adjusted to $15.5 \pm$ $0.5 \%$ (wet basis) prior to initiating storage trials. Numbers of live weevils, grain damage, weight loss, and weight of powder produced were assessed at the end of each storage time. As expected, severe damage was observed at $27^{\circ} \mathrm{C}$ and $90 \mathrm{~d}$ for all maize varieties. Grain damaged, percentage grain weight loss and weight of powder produced was significantly and positive correlated with number of live $S$. zeamais $(r 1 / 40.91, P<$ $0.05),(r 1 / 40.88, P<0.05)$, and $(r 1 / 40.89, P$ $<0.05)$ respectively.

\section{REFERENCES}

Abba, E. J. and A. Lovato (1999). Efect of seed storage temperature and relative humidity on maize (Zea mays L.) seed viability and vigour. Seed Sci. Technol. 27, 101-114

Baoua, I.B., L. Amadou, B. Ousmane, D. Baributsa and L.L. Murdock (2014). PICS bags for post-harvest storage of maize grain in West Africa. Journal of Stored Products Research 58: 20-28.

CoStat software program (Version 6.400). CoStat version 6.400 Copyright () 1998-2008 Cohort Software.798 Lighthouse Ave. PMB 320, Monterey, CA, 93940, USA.

Danho, M., C. Gaspar and Eric Haubruge (2002). The impact of grain quantity on the biology of Sitophilus zeamais Motschulsky (Coleoptera: Curculionidae): Oviposition, distribution of eggs, adult emergence, body weight and sex ratio. Journal of Stored Products Research 38(3):259266.

Kurdikeri, M.B., B. Aswathaialz, R.D. Katagall, S. Rajendraprasud and S. Vasudenvan (1994). Laboratory studies on extent of grain damage, loss in weight and viability due to infestation of the lesser grain borer Rhizopertha dominica (F.) in maize hybrids. Karnataka Journal of Agriculture Science 7(2): 186-189.

Ramzan, M., B.K. Judge, R.P. Urawa and D.D. Narang (1994). Assessment of storage losses in wheat at farm and puplic sector levels in Punjab. of Insect Science 7(2):187-190

Kurdikeri, M. B., B. Aswathaialz, S. Rajendraprusad, R.D. Katagall and 
S.C. Aswathanarayana (1995). Studies on relative grain damage- loss in weight and loss of viability caused by Sitophilus oryzae (L.) and Rhizopertha dominica (F.) in maize hybrids. Grain Research, 21(2): 72-77.

Lohar, M.K., H.U. Kakar and G.M. Juno (1995). Quantitative lossesof stored wheat, rice and maize caused by Sitophilus granaries (L.). Proceeding of Pakistan Congress of Zoology. 15: 246-246

Vowotor, K.A., N.A. Bosque-Perez and J.N. Ayerter (1995). Effect of maize variety and storage form on the development of the maize weevil, Sitophilus oryzae Motsch. Journal of Stored Products Research 31(1): 2936.

Thukur, A.K. and J.K. Sharma (1996). Assessment of storage losses in rice in Himachal Pradesh. Pest-
Management and Economic Zoology 4(1-2): 97-100.

Richter, J., A. Biliwa and S. HenningHelbig (1997). Losses and pest infestation in different maize storage systems with particular emphasis on Prostephanus truncates (Horn) (Coleoptera: Bostrichidae) in Togo Danho,M. ; C. Gaspar and E. Haubruge (2002). The impact of grain quantity on the biology of Sitophilus zeamais Motschulsky (Coleoptera: Curculionidae): oviposition, distribution of eggs, adult emergence, body weight and sex ratio. Journal of Stored Products Research 38: 259266.

Suleiman, R., K.A. Rosentrater and C.J. Bern (2015). Evaluation of maize weevils Sitophilus zeamais Motschulsky infestation on seven varieties of maize. Journal of Stored Products Research 64: 97-102. 
تأثير الاصابة بثلاثة انواع من سوس الحبوب على أوزان الحبوب المخزنة تحت الظروف المعملية لمدة عام

محمد الامين محمد سويلم، أحمد محمد عبد الرحيم، صفاء مصطفى أبو طاقة،

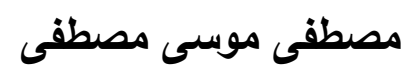

كلية الزراعة - جامعة المنوفية - شبين الكوم مصر فوليق

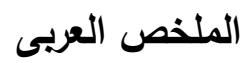

أجريت هذه الرسالة بمعامل كلية الزراعة جامعة المنوفية بغرض دراسة سلوك بعض الافات الحشرية التى تصيب الحبوب المخزونة بمحافظة المنوفية

حيث تم تخزين بعض الحبوب فى وسط مشابه للتخزين التقليدى فى البيئة المصرية، وهو التخزين المعتاد فى الثون تحت المظلات أو فى أجولة مصنوعة من الجوت، وكانت كالتالى:

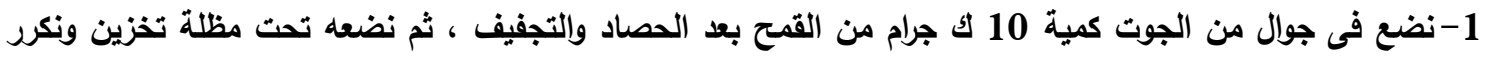
نفس الكمية من حبوب الأذرة وكنلك مثلها من حبوب الارز، وذلك مباشرة بعد مواعيد حصاد كل من المحاصيل الثلاثة: القمح والأذرة والارز

2- نأخذ عينة عشوائية من هذه الحبوب كل اسبوعين ونحسب نسبة الإصابة التى تحدث بها بعد العينة العشوائية وحصر المصاب بها وبيان نسبته بطريقة الثفافية.

3- يتم وزن كمية الحبوب من كل نوع وبيان مقار النقص فى وزن الاجولة الحاوية لأنواع الحبوب للمحاصيل الثلاثة يتم

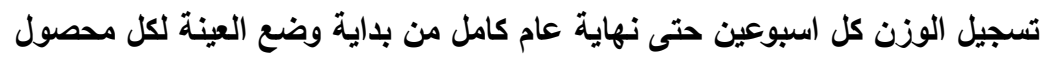

اثبتت الدراسة ان النقص فى وزن الحبوب يتزاوح بين 30 \% :60\% وقد تصل الى ان تترك الحشرة الحبوب وهى 
M.E. Sweelam, et al., 